\title{
The effect of parallel OTC-DVP bond market introduction on yield curve volatility ${ }^{*}$
}

\author{
Andraž Grum ${ }^{l}$
}

\begin{abstract}
The goal of this paper is to analyze the effect of OTC-DVP (over the counter delivery versus payment) fixed income market introduction in Slovenia on the term structure estimation and on the volatility of zero coupon yields and forward interest rates. For the purpose of the analysis Slovenian zero coupon and forward curves were estimated. The model used for yield curve estimation was Nelson-Siegel model as it proved to be superior in terms of goodness of fit, to other statistical methods of yield curve estimation, namely: Svensson model, B-splines model, smoothing B-splines model and Merrill Lynch exponential splines model. Results of analysis show that OTC-DVP bond market introduction (as parallel bond market) has improved the information content of bond prices for term structure estimation purpose. The volatility of spot and forward rates for mid and long remind maturities has fallen with the highest density on the longest maturity segment.
\end{abstract}

Key words: OTC-DVP bond market, term structure estimation, splines, NelsonSiegel model, yield volatility

JEL classification: 6120, G280, C610, C100

\section{Introduction}

The goal of this paper is to analyze the effect of OTC-DVP (over the counter delivery versus payment) fixed income market introduction on Slovenian term structure estimation and on the volatility of zero coupon yields and forward interest rates. For the purpose of the analysis Slovenian zero coupon and forward curves were estimated. The model used for yield curve estimation was Nelson-Siegel model as it proved to be superior in terms of goodness of fit, to other statistical methods of yield curve estimation, namely: Svensson model, B-splines model, smoothing B-splines

\footnotetext{
Received: 26-01-2006; accepted: 25-04-2006

1 MSc, PhD student at the Universitiy of Ljubljana, Faculty of Economics. Head of fund management sector, Triglav Asset Management Company LLC, Slovenska 54, 1000 Ljubljana, Slovenia. Scientific affiliation: finance. Phone: +386 51608 798, Fax: +386 13007 350, E-mail: andraz. grum@triglav-du.si, Personal website: http://www.triglav-du.si
} 
model and Merrill Lynch exponential splines model. The resulted estimates are to the knowledge of the author initial estimates of Slovenian term structure. When we write about yield curve or term structure function in the following text, we will be referring to zero coupon yield curve, forward curve or discount curve which can be algebraically shown as three different representations of the same thing - namely the term structure. All estimates will be made on continuously compounded interest rates.

Before OTC-DVP bond market introduction bonds were traded only on the official Ljubljana stock exchange market, but the liquidity of the market was poor. Therefore prices used as input for yield curve calculation were not good representative of market conditions. Our main hypothesis is that the introduction of OTC-DVP market has improved the information value of input prices for the purpose of term structure estimation through the elimination of low liquidity effect. The main reason can be found in institutional investors which act as market makers. They are obligate to qoute bid and ask prices for listed fixed income instruments and even more important - they are obligated to do trades within qouted bid/ask spread. Consequently instrument prices more acurately represent current market conditions and can be used as good input data regardless the actual volumne of transactions or liquidity. We expect paralell market introduction to improve the qualitiy of estimations in terms of goodness of fit and that improved estimates will reduce the volatility of estimated spot and forward yields.

To test our hypothesis we will have to obtain initial estimates of Slovenian term structure. After the introduction there is a brief theoretical overview of methods used for static yield curve modeling. Then the Slovenian market environment and the introduction of OTC-DVP market are explained in more detail. At the end the results of analyses are presented.

\section{Theoretical overview}

Static methods of yield curve estimation are usually separated in two groups, namely parametric and spline methods. In the spline subgroup B-splines are the most commonly used estimation method, as they have proven to be numerically stable. In the parametric methods subgroup Nelson-Siegel (1987) and Svensson (1994) models are usually applied. Because of the robust estimation results central banks from developed financial markets usually use parametric models for monetary analyses purposes. The main advantage of splines is their high flexibility, which makes the method very suitable when the yield curve is estimated for the purpose of valuation of financial instruments. On the other hand parametric methods are less flexible and more robust and are usually applied for the purpose of conducting monetary policy where the most important factor of estimation are stable and theoretically sound forward rates. 


\subsection{Splines}

Spline is segmented polynomial composed from individual polynomials of the degree $k$ and defined on the sequence of knots (De Boor, 2003). The main characteristic of splines as the method of yield curve estimation is the fact that for the purpose of term structure estimation maturity spectrum is segmented in subintervals. The parameters of splines are estimated in the way to achieve the best fit of the function on specific subinterval. McCulloch (1971 and 1975) proposed the application of quadratic and cubic splines. McCulloch (1975), Litzenberger and Rolfo (1984) and Jordan (1984) explicitly analyzed the effect of taxation on yield curve estimation. Vasicek and Fong (1982) estimated discount function with exponential splines. Schaefer (1973 and 1981) suggested using Bernstein polynomials. Shea (1984) and Steeley (1991) introduced the application of cubic B-splines in yield curve estimation. The latest proved to be the most suitable because of their numerical stability and are the most commonly applied in practice (Ioannides, 2003:6). One of the most important application are smoothed B-splines presented by Fisher, Nychka and Zervos (1994). They introduced penalty function in the objective function to penalize excess volatility of forward interest rates for different maturities. Waggoner (1997) extended the idea by introduction of penalty function which values are a function of remind maturity. Anderson and Sleath (2001) applied the model to the Britain fixed income market and indexed bonds to estimate inflation maturity structure.

\subsection{Parametric methods of yield curve estimation}

Parametric models of yield curve estimation are also known as parsimonious models as they are based on parsimonious parameterization of chosen term structure function. Parsimonious estimation models are trying to estimate the yield curve as linear combination of chosen unsegmented basis functions, defined on the entire maturity interval. The parameters of model are estimated in the way to minimize the sum of square residuals between actually observed and theoretical bond prices or yields to maturity. Parametric method for yield curve estimations was pioneered by Nelson and Siegel (1987) and further developed by Svensson (1994) and Li et al. (2001). Parametric methods differ in the type of estimated term structure function, namely discount function, zero coupon yield curve or forward curve, where the latest being the most commonly in focus.

\subsubsection{Merrill Lynch exponential spline model}

In Merrill Lynch exponential spline model (MLES) (Li et al., 2001) the function being estimated is discount function which is modeled as linear combination of basic exponential functions defined on the entire maturity interval:

$$
d(m)=\sum_{k=1}^{D} \zeta_{k} e^{-k a m}
$$

$d(m)$ - discount function as function of remind maturity

$\xi_{\mathrm{k}}$ - unknown parameters for $k=1, \ldots, D$

$\alpha$ - long term instantaneous forward interest rate 


\subsubsection{Nelson-Siegel and Svensson model}

In the parametric model subgroup the most commonly applied model is the Nelson-Siegel (1987) model. It was extended by Svensson (1994) and for that reason the latest is also known as extended Nelson-Siegel model. The basic concept of the model is in the parsimonious estimation of instantaneous forward curve. Algebraically the function is derived as solution to the second degree differential equation with equal real roots. The shape of the function provides several advantages:

- it can be used in different market environments with different term structure shapes, humped, monotone and/or S shaped;

- model is parsimonious as only four parameters need to be estimated;

- estimated forward curve has desired theoretical characteristics - it is smooth and asymptotical and last but not least;

- estimated function can be extrapolated.

Nelson-Siegel (1985:8) suggested forward curve to be estimated as:

$$
f(m, \beta)=\beta_{0}+\beta_{1} e^{\left(\frac{-m}{\tau_{1}}\right)}+\beta_{2} \frac{m}{\tau_{1}} e^{\left(\frac{-m}{\tau_{1}}\right)}
$$

Besides being parsimonious the model has another advantage, namely interesting economic interpretation of parameters and good asymptotical characteristics (Seppälä and Viertiö, 1996:17). It holds $\lim _{m \rightarrow \infty} f(m, \beta)=\beta_{0}$ and $\lim _{m \rightarrow \infty} f(m, \beta)=\beta_{0}+\beta_{1}$. The value of parameter $\beta_{0}$ represents the asymptote of zero coupon yield curve function and at the same time the asymptote of forward curve as remained maturity approaches to infinity and can be interpreted as long term interest rate. The sum of parameters $\beta_{0}+\beta_{1}$ represent initial value of forward curve $\left(f(0)=\beta_{0}+\beta_{1}\right)$, which can be interpreted as instantaneous spot interest rate. The value of parameter $\beta_{1}$ represents the deviation of the function values from the asymptote and can intuitively be explained as the curvature of the function or as the difference between long term and short term forward interest rates. Parameters $\beta_{0}$ and $\left(\beta_{0}+\beta_{1}\right)$ must be positively valued.

The value and the sign of parameter $\beta_{2}$ define the magnitude and the direction of the hump. If the value of the parameter is negative, then the term structure is $U$ shaped. If the parameter has positive sign, the term structure is humped. The value of parameter $\tau_{1}$ must be positive and it defines the location of the hump on the maturity spectrum. The parameters of instantaneous forward rate function that have to be estimated are $\beta$ $=\left(\beta_{0}, \beta_{1}, \beta_{2}, \tau_{1}\right)$. The facilitating fact is that the model is linear in $\beta_{0}, \beta_{1}$ in $\beta_{2}$ for chosen value of parameter $\tau_{1}$ and that the parameters have the same value on the entire maturity interval. Applied functionality guarantees term structure function to be smooth and at the same time sufficiently flexible. 
Svensson (1994:6) extended Nelson-Siegel model by introducing additional parameters that allow term structure function to have additional hump. Schich (1997:15) and Ricart and Sicsic (1995:52) find application of Svensson model to be desirable in the highly uncertain environment on the financial markets. Svensson model is computably more demanding. In most cases in practice application of the model does not significantly improve the results obtained with Nelson-Siegel model and is that fore questionable. Svensson (1994:7) suggested forward curve to be estimated as:

$$
f(m, \beta)=\beta_{0}+\beta_{1} e^{\left(\frac{-m}{\tau_{1}}\right)}+\beta_{2} \frac{m}{\tau_{1}} e^{\left(\frac{-m}{\tau_{1}}\right)}+\beta_{3} \frac{m}{\tau_{2}} e^{\left(\frac{-m}{\tau_{2}}\right)}
$$

Interpretation of the parameters is identical to Nelson-Siegel model where the additional parameters $\tau_{2}$ and $\beta_{3}$ have the same characteristics as $\tau_{1}$ and $\beta_{2}$.

\section{Estimation procedure}

For the purpose of Nelson-Siegel model parameter estimation, we have to derive the discount function from the zero-coupon yield function $(\mathrm{z}(m, \beta))$, namely:

$$
d(m, \beta)=e^{\left(-\frac{z(m, \beta)}{100} m\right)}
$$

The parameters of discount function are estimated as sum of square residuals optimization between theoretical and actually observed bond prices, where the estimated discount function for given parameter $\left(\tau_{1}, \beta_{0}, \beta_{1}\right.$ and $\left.\beta_{2}\right)$ values serves as input in theoretical bond price calculation:

$$
\hat{P}_{j}\left(m_{j}, \beta\right)=\sum_{k=1}^{K_{i}} C_{j k} \cdot \hat{d}\left(\tau_{j k}, \beta\right)+V_{j} \cdot \hat{d}\left(\tau_{j K j}, \beta\right) ; j=1, \ldots, N
$$

The above equation is nonlinear in unknown parameters $\left(\tau_{1}, \beta_{0}, \beta_{1}\right.$ and $\left.\beta_{2}\right)$ and as a consequence parameters can not be estimated with simple regression. Svensson (1994:7) suggests that parameters can be estimated with maximum likelihood method, with nonlinear least squares or with generalized method of moments.

In the optimization process the value of parameters $\left(\tau_{1}, \beta_{0}, \beta_{1}\right.$ and $\left.\beta_{2}\right)$ is set under condition of objective function value minimization; where as the objective function is defined as a difference between theoretical and observed bond prices:

$$
\min _{\beta_{0}, \beta_{1}, \beta_{2}, \tau_{1}, \tau_{2}} \sum_{j=1}^{N}\left[P_{j}\left(m_{j}\right)-\hat{P}_{j}\left(m_{j}, \beta\right)\right]^{2}
$$

The utilization of price difference in objective function is commonly used in practice, as the method is numerically relatively undemanding. The shortcoming of the method is the fact that it can lead to relatively large errors in estimated yields to 
maturity on the short maturity segment (Schich, 1997:18). Relative price change of fixed income instrument is equal to the product of modified duration and the change in yield to maturity. For instruments with short remind maturity, the modified duration is small. High relative price volatility is therefore inventible reflexed in even higher yield to maturity volatility. As a result price errors are more the proportionally reflected in yield errors. Price differential is not suitable objective function on short maturity segment. The problem can be solved by applying weighted price errors method or by applying yield errors method. If the weighted price errors method is applied, then the objective function can be written as (Bolder and Gusba, 2002:47; Dombrecht and Wouters, 1999:1):

$$
\begin{gathered}
\min _{\beta} \sum_{j=1}^{N}\left[\frac{P_{j}\left(m_{j}\right)-\hat{P}_{j}\left(m_{j}, \beta\right)_{i}}{\Phi_{j}}\right]^{2} \\
\text { where } \Phi_{j}=D_{j} \cdot \frac{P_{j}}{1+y_{j}}=M D_{j} \cdot P_{j}
\end{gathered}
$$

$P_{j}$ - observed price of $j$-th financial instrument

$\hat{P}_{j}$ - theoretical price of $j$-th financial instrument, calculated on the basis of estimated term structure (discount function)

$D_{j}$ - duration of $j$-th financial instrument

$M D_{j}$ - modified duration of $j$-th financial instrument

$y_{j}-$ yield to maturity of $j$-th financial instrument

\section{Fixed income market environment in Slovenia}

Despite the importance of term structure for business and monetary purposes Slovenian term structure was not yet estimated. Partly the blame goes to undeveloped bond market, characterized by high portion of foreign currency issues by Slovenian government, the lack of long term instruments and low liquidity on the secondary market (Grum, 2005:28). In the last two years state treasury has been systematically issuing only Slovenian SIT denominated bonds with fixed nominal interest rate for the purpose of systematic yield curve building. For the purpose of fulfilling Maastricht's long term interest rate rule the focus has been on the longest maturity term structure segment. Issuing plan for year 2005 expects treasury to issue long term bond with 11 years and 1 month maturity, which will represent benchmark bond

In 2001, OTC-DVP (over the counter delivery versus payment) market was introduced for treasury bills and the results have been encouraging - the liquidity of the market has improved (Dolenc, 2003:228). To improve the liquidity of the 
secondary bond market in September 2005 OTC-DVP bond market was introduced. The market operates as institutional market with official market makers and it is working parallel to official Ljubljana stock exchange market. Before OTC-DVP market introduction bonds were traded only on the official Ljubljana stock exchange market, but the liquidity of the market was pore. Therefore prices used as input for yield curve calculation were not good representative of market conditions. Introduction of OTC-DVP market has improved the liquidity of Slovenian bonds and it can be expected that the information value of bond prices as inputs in term structure estimation has also improved.

\section{Data and yield curve estimation}

Slovenian term structure will be estimated on the basis of government bond and treasury bill prices for the period between $1^{\text {st }}$ January 2005 and $28^{\text {th }}$ February 2006. Among bonds index linked bonds and callable bonds will be eliminated. To assure sensible input prices, liquidity and remaining maturity will also represent inclusion criterion. Included bonds are: RS44, RS51, RS54, RS55, RS56, RS57, RS58, RS59 and RS60. From $24^{\text {th }}$ January 2006 two new issues are included in the estimation, namely RS61 in RS62. Because of the issuing system there are 16 different active treasury bills with different remaining maturity in circulation on every estimation day. All of the selected instruments are quoted on parallel OTC-DVP market. Because of the short remaining maturity and extreme yield fluctuations bond RS51 was excluded from estimation. In November 2005 Slovenian Ministry of finance has stopped issuing one-month treasury bills. As a result there are 12 different treasury bills with different remaining maturity in circulation on every estimation day.

We will use quotes for treasury bills and bonds on OTC-DVP market that the market makers are quoting on 11 am on the estimation day. The benchmark hour appointment is experience based, as market makers usually quote all their instruments up to appointed hour. After that quotes are rarely changed, rather they are withdrawn. There is also formal reasoning - along the Agreement of Slovenian inter bank market interest rates settlement - SITIBOR is calculated on the basis of inter bank market interest rate quotes quoted by eight largest Slovenian banks on 11 am every day.

Market makers quote ask and bid price for every financial instrument they are willing to trade. The average between bid and ask price will be used as representative price of certain financial instrument set by certain market maker. Different market makers quote different prices for the same instruments. The representative price of financial instrument for certain day which serves as input price in term structure estimation is calculated as average of representative prices set by individual market maker. OTC-DVP bond market was introduced on $1^{\text {st }}$ November 2005. Before that bonds were traded only on the Ljubljana Stock Exchange and the official exchange price will be used as input for that period. 


\subsection{Yield curve estimation results}

On the basis of presented estimation methodology and using input prices for government bills and bonds from OTC-DVP market we estimated term structure for time period ranging from 1. January 2005 to 28 . February 2006. Parameters were estimated on the basis of weighted price error minimization. The parameter estimation was implemented using non-linear least square procedure in Matlab. Methods were compared in terms of goodness of fit, more exactly; they were compared on the basis of root square mean error (RMSE), mean absolute error (MAE), mean percentage error (MPE) and hit ratio (HR). Hit ratio is defined as proportion of correctly priced securities between all securities. The security is correctly priced if its theoretical value calculated on the basis of estimated term structure, falls in the range between bid and ask price of that security on the day of estimation.

\subsubsection{Estimation before OTC-DVP bond market introduction}

Estimation period should be separated in two sub periods. The first sup period corresponds to the period from 1. January 2005 to OTC-DVP market introduction on 1. September 2005. In the first sub period bonds were quoted only on Ljubljana stock exchange official market and volume weighted average daily price was used as input to estimation. The information value of instrument prices was found to be poor for the purpose of yield curve estimation, as liquidity was not satisfactory. Between tested methods only Nelson-Siegel model proved to be robust enough to systematically produce economically sound estimates of yield curve. Even estimates obtained with the application of Nelson-Siegel model proved to be highly volatile.

The scarcity of instruments available on the market and their poor liquidity disabled other more flexible estimation methods to systematically produce economically sound yield curve estimations. Smoothing B-spline method produced economically sound results if sufficiently high value of penalty function was applied but only if we were willing to sacrifice goodness of fit on the short term segment. McCulloch knots scheme did not yield good results as density of observations on the short segment was disproportionably high when compared to other segments. As a result too many knots were set on the short maturity segment and the volatility of short term rates was high. Sound results were obtained if second knot was set to the maturity of around one year or alternativelly with McCulloch knot scheme in combination with sufficiently high value of penalty function.

MLES parametric method also proved to be to flexible. If applied number of basis exponential functions exceeded five, then estimated zero-coupon yields and forward interest rates were to volatile. If less basis functions were applied, then the estimated term structure was to stiff or almost linear and understandably not flexible enough. As a result the goodness of fit on all maturity segments was poor. 
Andraž Grum $\bullet$ The effect of parallel OTC-DVP bond market...

\subsubsection{Estimation after OTC-DVP bond market introduction}

The second sub period corresponds to the period after parallel OTC-DVP market introduction (1. September 2005) and ranges to the end of estimation period (28. February 2006). As it will be seen from results, the information value of input prices for the purpose of yield curve estimation has improved dramatically in the second sub period and the volatility of estimated yields has fallen. Unfortunately the second sub period findings confirmed the first sub period findings, namely B-spline methods and MLES model proved to be to complex to systematically produce economically sound term structure estimates. The main reason for that is the scarcity of government instruments, especially on the longer maturity segment. In practice it was found out that MLES model could on certain days give marginally better result in terms of goodness of fit when compared to Nelson-Siegel model. On other days the implementation of the same model resulted in very poor estimates. B-splines and smoothing B-splines systematically under performed Nelson-Siegel model and MLES model.

Among tested methods only Nelson-Siegel model proved to be robust enough to give sound estimates in the second sub period. Application of Svensson model in many cases did not improve estimation results. In many case algorithm did not reach convergence in other technique proved to be computational time and resource consuming. Two hump term structure suggested by Svensson model offers flexibility not needed on the instrument poor Slovenian government fixed income market.

B-splines and MLES parametric model were not robust enough as they are highly dependent on the number of instruments included in the estimation. In the case of Slovenia, this is especially true in the mid and long term segment because of the longer term bond scarcity. From 24. January 2006 when two new bond issues (RS61 and RS62) were included in the estimation the quality of estimates obtained with MLES model and (smoothing) B-spline model has improved. As long term yields were found to be highly volatile we could expect that estimations would improve if government would issue bond with 15 or 20 years remain maturity. We expect flexible methods to improve their value for Slovenian term structure estimation with new government bond issues. 
Figure 1: Nelson-Siegel model parameter values in the estimation period

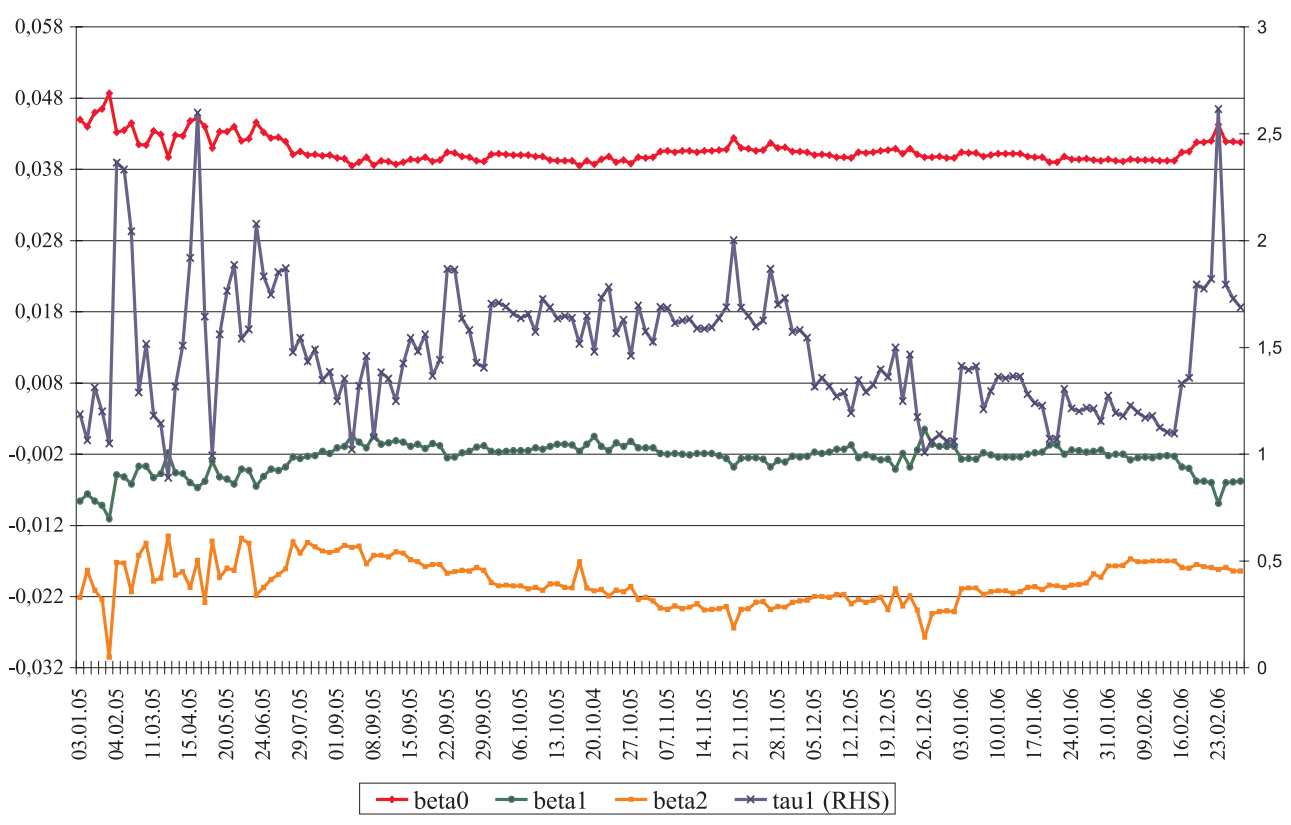

Source: Own calculations

Figure 1 shows the evolution of Nelson-Siegel model parameter values in the estimation period. Left hand side scale represents values of betas and right hand side scale represent value of tau1. Long term interest rate presented by parameter $\beta_{0}$ value has not changed dramatically in the estimation period. 11 years interest rate varied in the range between $3.78 \%$ and $4.47 \%$, long term interest rate calculated as limit value when maturity is approaching infinity varied between $3.85 \%$ and $4.87 \%$. Short term interest rates calculated as the sum of parameter $\beta_{0}$ and parameter $\beta_{1}$ values has in the estimation period slightly increased, though they have varied in small range. If we neglect extreme value estimated on 26. December 2005 (4.12\%), then short term interest rates varied in the range between $3.54 \%$ and $3.93 \%$. 
Andraž Grum $\bullet$ The effect of parallel OTC-DVP bond market..

Zb. rad. Ekon. fak. Rij. • $2006 \cdot$ vol. $24 \cdot s v .1 \cdot 123-140$

Table 1: Term structure estimates obtained with Nelson-Siegel model

\begin{tabular}{|c|c|c|c|c|c|c|c|c|c|c|}
\hline & \multicolumn{5}{|c|}{ Before OTC-DVP market (1.1.05-31.8.05) } & \multicolumn{5}{|c|}{ After OTC-DVP market (1.9.05-28.2.06) } \\
\hline & Mean & $\begin{array}{l}\text { Standard } \\
\text { deviation }\end{array}$ & Min & Max & $\mathrm{KV}(\%)$ & Mean & $\begin{array}{l}\text { Standard } \\
\text { deviation }\end{array}$ & Min & Max & $\mathrm{KV}(\%)$ \\
\hline 1 & 2 & 3 & 4 & 5 & 6 & 7 & 8 & 9 & 10 & 11 \\
\hline beta 0 & 0.04288 & 0.00208 & 0.0397 & 0.0487 & 4.86 & 0.03998 & 0.00089 & 0.0385 & 0.0443 & 2.22 \\
\hline beta 1 & -0.00496 & 0.00223 & -0.0111 & -0.0016 & -44.89 & -0.00193 & 0.00146 & -0.0089 & 0.0015 & -75.78 \\
\hline beta 2 & -0.01828 & 0.00346 & -0.0305 & -0.0135 & -18.93 & -0.02044 & 0.00268 & -0.0277 & -0.0148 & -13.09 \\
\hline tau 1 & 1.57019 & 0.40442 & 0.8898 & 2.5991 & 25.76 & 1.45725 & 0.25065 & 1.0090 & 2.6163 & 17.20 \\
\hline RMSE & 51.65485 & 34.53156 & 14.5428 & 152.9435 & 66.85 & 23.41879 & 19.52945 & 5.4172 & 107.1674 & 83.39 \\
\hline MAE & 27.39231 & 16.57603 & 9.7586 & 71.6042 & 60.51 & 12.15615 & 7.75999 & 3.5949 & 47.0397 & 63.84 \\
\hline MPE & -0.00004 & 0.00007 & -0.0002 & 0.0001 & -183.91 & 0.00001 & 0.00004 & -0.0001 & 0.0002 & 435.81 \\
\hline HR & $67.39 \%$ & 0.05803 & $42.11 \%$ & $76.19 \%$ & 8.61 & 0.97569 & 0.05791 & $43.48 \%$ & $100.00 \%$ & 5.94 \\
\hline \multicolumn{11}{|l|}{$\mathrm{z}$} \\
\hline $1 \mathrm{M}$ & $3.76 \%$ & 0.00052 & $3.60 \%$ & $3.85 \%$ & 1.39 & $3.75 \%$ & 0.00076 & $3.53 \%$ & $4.01 \%$ & 2.03 \\
\hline $3 \mathrm{M}$ & $3.69 \%$ & 0.00061 & $3.52 \%$ & $3.80 \%$ & 1.64 & $3.66 \%$ & 0.00067 & $3.50 \%$ & $3.81 \%$ & 1.84 \\
\hline $6 \mathrm{M}$ & $3.62 \%$ & 0.00069 & $3.44 \%$ & $3.77 \%$ & 1.90 & $3.55 \%$ & 0.00062 & $3.45 \%$ & $3.66 \%$ & 1.76 \\
\hline $9 \mathrm{M}$ & $3.57 \%$ & 0.00071 & $3.39 \%$ & $3.74 \%$ & 1.98 & $3.47 \%$ & 0.00061 & $3.36 \%$ & $3.60 \%$ & 1.77 \\
\hline $1 \mathrm{Y}$ & $3.54 \%$ & 0.00068 & $3.36 \%$ & $3.71 \%$ & 1.93 & $3.40 \%$ & 0.00061 & $3.28 \%$ & $3.55 \%$ & 1.78 \\
\hline $2 \mathrm{Y}$ & $3.50 \%$ & 0.00052 & $3.42 \%$ & $3.66 \%$ & 1.47 & $3.30 \%$ & 0.00055 & $3.20 \%$ & $3.47 \%$ & 1.66 \\
\hline $3 \mathrm{Y}$ & $3.54 \%$ & 0.00069 & $3.45 \%$ & $3.67 \%$ & 1.95 & $3.32 \%$ & 0.00054 & $3.25 \%$ & $3.48 \%$ & 1.63 \\
\hline $4 \mathrm{Y}$ & $3.61 \%$ & 0.00096 & $3.50 \%$ & $3.87 \%$ & 2.67 & $3.37 \%$ & 0.00057 & $3.28 \%$ & $3.53 \%$ & 1.68 \\
\hline $5 \mathrm{Y}$ & $3.68 \%$ & 0.00117 & $3.55 \%$ & $4.03 \%$ & 3.18 & $3.44 \%$ & 0.00058 & $3.33 \%$ & $3.58 \%$ & 1.69 \\
\hline $6 \mathrm{Y}$ & $3.75 \%$ & 0.00131 & $3.61 \%$ & $4.15 \%$ & 3.49 & $3.50 \%$ & 0.00057 & $3.38 \%$ & $3.63 \%$ & 1.62 \\
\hline $7 Y$ & $3.80 \%$ & 0.00140 & $3.66 \%$ & $4.25 \%$ & 3.67 & $3.55 \%$ & 0.00054 & $3.44 \%$ & $3.67 \%$ & 1.53 \\
\hline $8 \mathrm{Y}$ & $3.85 \%$ & 0.00146 & $3.70 \%$ & $4.33 \%$ & 3.78 & $3.60 \%$ & 0.00052 & $3.49 \%$ & $3.70 \%$ & 1.44 \\
\hline $9 \mathrm{Y}$ & $3.90 \%$ & 0.00150 & $3.73 \%$ & $4.39 \%$ & 3.85 & $3.64 \%$ & 0.00050 & $3.53 \%$ & $3.74 \%$ & 1.37 \\
\hline $10 \mathrm{Y}$ & $3.93 \%$ & 0.00154 & $3.76 \%$ & $4.43 \%$ & 3.91 & $3.67 \%$ & 0.00049 & $3.57 \%$ & $3.78 \%$ & 1.33 \\
\hline $11 \mathrm{Y}$ & $3.96 \%$ & 0.00156 & & & 3.95 & $3.70 \%$ & 0.00048 & & $3.82 \%$ & 1.31 \\
\hline \multicolumn{11}{|l|}{$\mathrm{f}$} \\
\hline $1 \mathrm{M}$ & $3.72 \%$ & 0.00057 & $3.55 \%$ & $3.82 \%$ & 1.54 & $3.70 \%$ & \begin{tabular}{|l|}
0.00071 \\
\end{tabular} & $3.51 \%$ & $3.90 \%$ & 1.92 \\
\hline $3 \mathrm{M}$ & $3.61 \%$ & 0.00074 & $3.42 \%$ & $3.76 \%$ & 2.04 & $3.53 \%$ & 0.00064 & $3.43 \%$ & $3.65 \%$ & 1.82 \\
\hline $6 \mathrm{M}$ & $3.50 \%$ & 0.00081 & $3.28 \%$ & $3.70 \%$ & 2.32 & $3.36 \%$ & 0.00070 & $3.19 \%$ & $3.51 \%$ & 2.08 \\
\hline $9 \mathrm{M}$ & $3.44 \%$ & 0.00074 & $3.26 \%$ & $3.65 \%$ & 2.15 & $3.25 \%$ & \begin{tabular}{|l|l|}
0.00073 \\
\end{tabular} & $3.06 \%$ & $3.43 \%$ & 2.25 \\
\hline $1 \mathrm{Y}$ & $3.42 \%$ & 0.00064 & $3.32 \%$ & $3.62 \%$ & 1.88 & $3.20 \%$ & 0.00072 & $3.01 \%$ & $3.38 \%$ & 2.26 \\
\hline $2 \mathrm{Y}$ & $3.53 \%$ & 0.00120 & $3.39 \%$ & $3.84 \%$ & 3.41 & $3.25 \%$ & 0.00080 & $3.12 \%$ & $3.44 \%$ & 2.45 \\
\hline $3 \mathrm{Y}$ & $3.73 \%$ & 0.00186 & & $4.31 \%$ & 4.99 & $3.45 \%$ & 0.00095 & $3.27 \%$ & $3.62 \%$ & 2.75 \\
\hline $4 \mathrm{Y}$ & $3.90 \%$ & 0.00210 & $3.69 \%$ & $4.59 \%$ & 5.39 & $3.63 \%$ & 0.00090 & $3.44 \%$ & $3.76 \%$ & 2.47 \\
\hline $5 \mathrm{Y}$ & $4.03 \%$ & 0.00212 & $3.82 \%$ & $4.74 \%$ & 5.26 & $3.76 \%$ & 0.00075 & $3.60 \%$ & $3.87 \%$ & 2.01 \\
\hline $6 \mathrm{Y}$ & $4.12 \%$ & 0.00207 & $3.90 \%$ & $4.81 \%$ & 5.02 & $3.85 \%$ & 0.00065 & $3.71 \%$ & $3.98 \%$ & 1.68 \\
\hline $7 Y$ & $4.18 \%$ & 0.00202 & $3.94 \%$ & $4.84 \%$ & 4.84 & $3.91 \%$ & 0.00062 & $3.77 \%$ & $4.05 \%$ & 1.58 \\
\hline $8 \mathrm{Y}$ & $4.21 \%$ & 0.00200 & $3.97 \%$ & $4.86 \%$ & 4.75 & $3.94 \%$ & 0.00065 & $3.80 \%$ & $4.13 \%$ & 1.65 \\
\hline $9 \mathrm{Y}$ & $4.24 \%$ & 0.00200 & $3.97 \%$ & $4.86 \%$ & 4.72 & $3.97 \%$ & 0.00070 & $3.82 \%$ & $4.20 \%$ & 1.77 \\
\hline $10 \mathrm{Y}$ & $4.26 \%$ & 0.00201 & $3.97 \%$ & $4.87 \%$ & 4.72 & $3.98 \%$ & 0.00075 & $3.83 \%$ & $4.26 \%$ & 1.89 \\
\hline $11 \mathrm{Y}$ & $4.27 \%$ & 0.00202 & $3.97 \%$ & $4.87 \%$ & 4.74 & $3.99 \%$ & 0.00079 & $3.84 \%$ & $4.30 \%$ & 1.98 \\
\hline
\end{tabular}

Source: Own calculations 
Table 1 presents aggregated results of term structure estimation in two sub periods. It includes estimated model parameter values, the value of spot and forward yields for standardized maturities ranging from 1 month to 11 years and their average value, standard deviation, minimum value, maximum value and coefficient of variation. One of the advantages of Neslon-Siegle model is the fact that estimated yields can be easily extrapolated as long term yields are expected to asimptotically converge to a constant (Meier, 1999:3). Regardless the possibility of extrapolation in this research yields were not estimated for maturities longer then maturity of the longest maturiy bond included in the estimation.

Table 2: Change in goodness of fit because OTC-DVP market introduction

\begin{tabular}{|l|c|c|c|}
\hline & $\begin{array}{c}\text { Average after } \\
\text { OTC-DVP }\end{array}$ & $\begin{array}{c}\text { Average before } \\
\text { OTC-DVP }\end{array}$ & Change (\%) \\
\hline RMSE & 23.420 & 51.655 & -54.66 \\
\hline MAE & 12.160 & 27.392 & -55.62 \\
\hline MPE & 0.00001 & -0.00004 & -79.84 \\
\hline HR (\%) & 97.57 & 67.39 & 44.79 \\
\hline
\end{tabular}

Source: Own calculations

OTC-DVP bond market introduction has improved the information value of bond prices for the purpose of term structure estimation meassured on the basis of goodness of fit. Table 2 shows that the goodness of fit error had decreased for more than $50 \%$ and at the same time the volatility of estimated spot and forward yields has been reduced (table 1). The main reason can be found in institutional investors which act as market makers. They are obligate to qoute bid and ask prices for listed fixed income instruments and even more important - they are obligated to do transaction within qouted bid/ask spread. Consequently instrument prices more acurately represent current market conditions and can be used as good input data regardless the actual volumne of transactions or liquidity. Fore that reason the effect of low liquidity on input prices for the porpose of term structure estimation has been reduced dramatically after OTC-DVP bond market introduction. 
Andraž Grum • The effect of parallel OTC-DVP bond market...

Figure 2: The root mean squared errors (RMSE) between estimated and actually observed prices

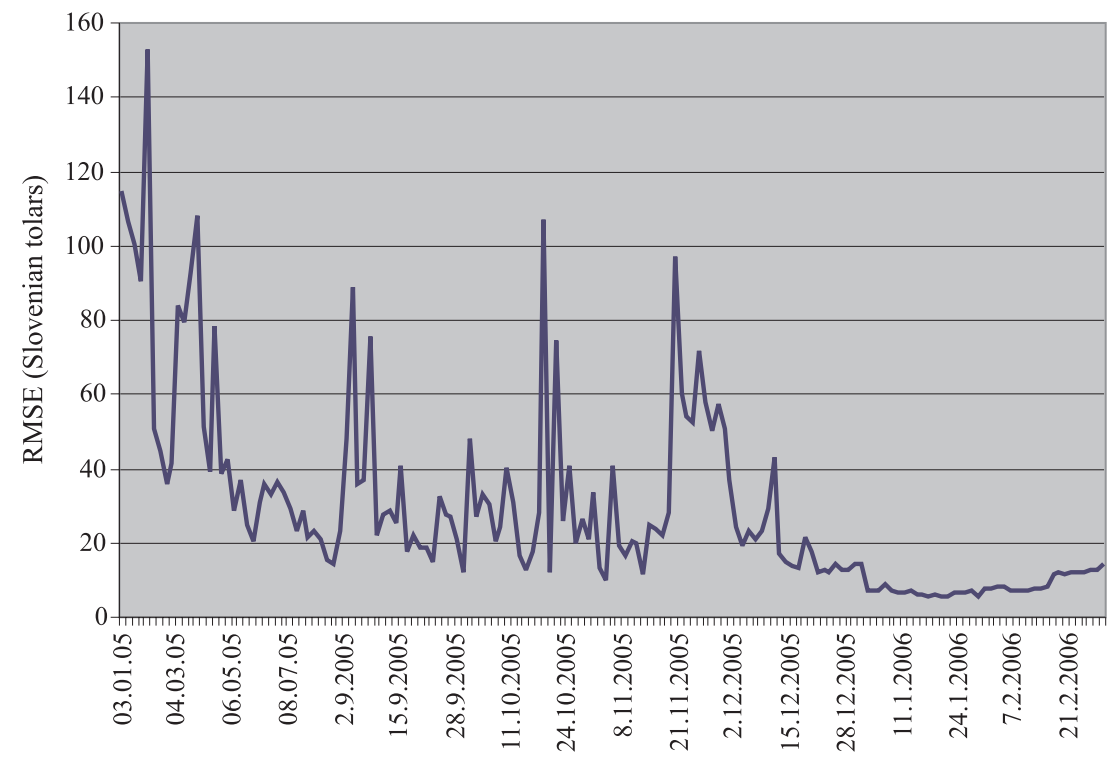

Source: Own calculations

Figure 2 presents the root mean squared errors (RMSE) between estimated and actually observed fixed income instrument prices in the estimated period. The RMSE is calcualted in Slovenian tolars (SIT), as dirty prices of fixed income instruments represent the input data. The nominal value of all instruments included in the analysis is 10,000 SIT. If we neglect the accrued interest than 20 SIT absolute RMSE value roughly corresponds to $0.2 \%$ relative RMSE. The value of RMSE has been falling during the estimation period and stabilised at level below 20 SIT which was reached in mid December 2005. In last 2.5 months of the estimation Nelson-Siegel model proved to be very robust.

\subsection{Volatility analysis results}

Figures 2 and 3 show the difference in weekly volatility of zero-coupon yields and forward interest rates before and after OTC-DVP bond market introduction. The volatility is measured as standard deviation of weekly estimates and it is presented on left hand scale. The difference in volatility befor and after OTC-DVP bond market introduction is presented on right hand side scale. With OTC-DVP bond market introduction the volatility of spot and forward rates for mid and long remind maturities has fallen. Volatility was found to be extremely reduced for longest maturity yields. For 10 year maturity bond zero-coupon yield volatility has fallen from 0.154 percentage points to 0.049 percentage points or for 0.105 percentage points. This is extremely important, as 10 year benchmark bond yield is closely observed as one of Maastricht's criteria which have to be implemented before joining 

Zb. rad. Ekon. fak. Rij. • $2006 \cdot$ vol. $24 \cdot s v .1 \cdot 123-140$

the EMU. The volatility reduction is desirable as it facilitate the monetary policy conduction.

Figure 3: Change in zero-coupon yields volatility

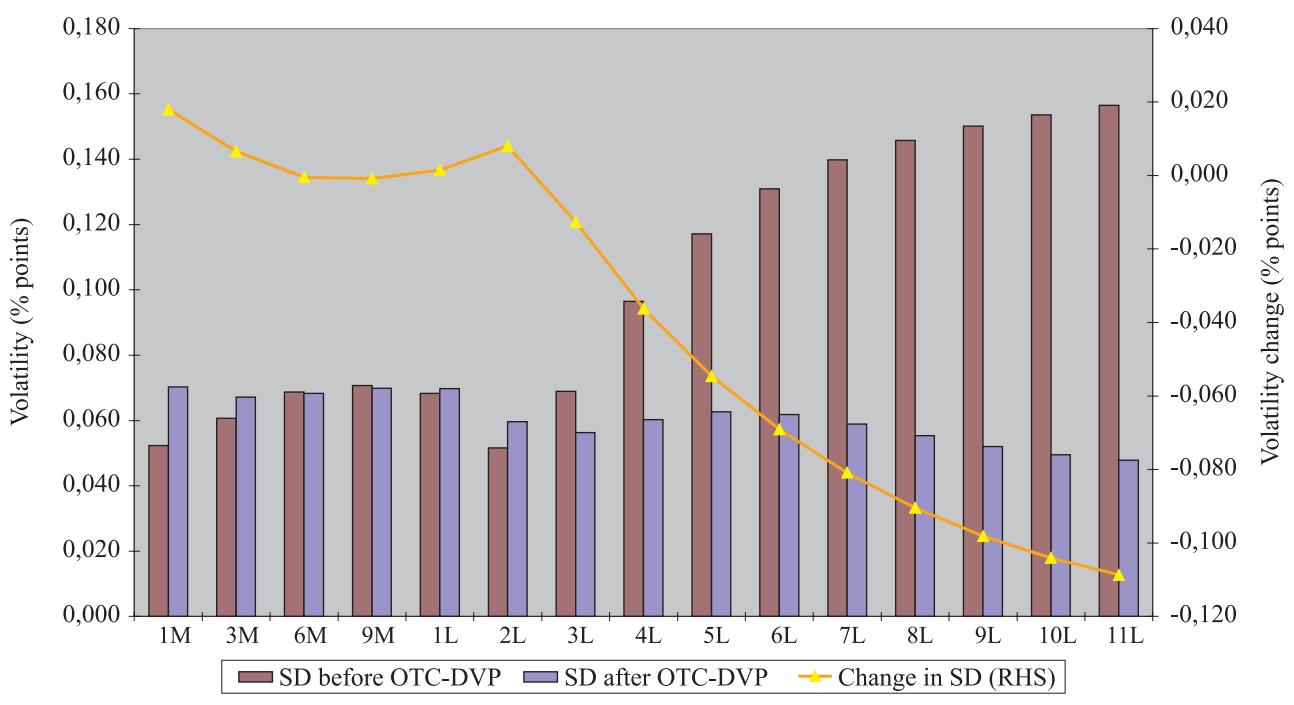

Source: Own calculations

Figure 4: Change in forward interest rates volatility

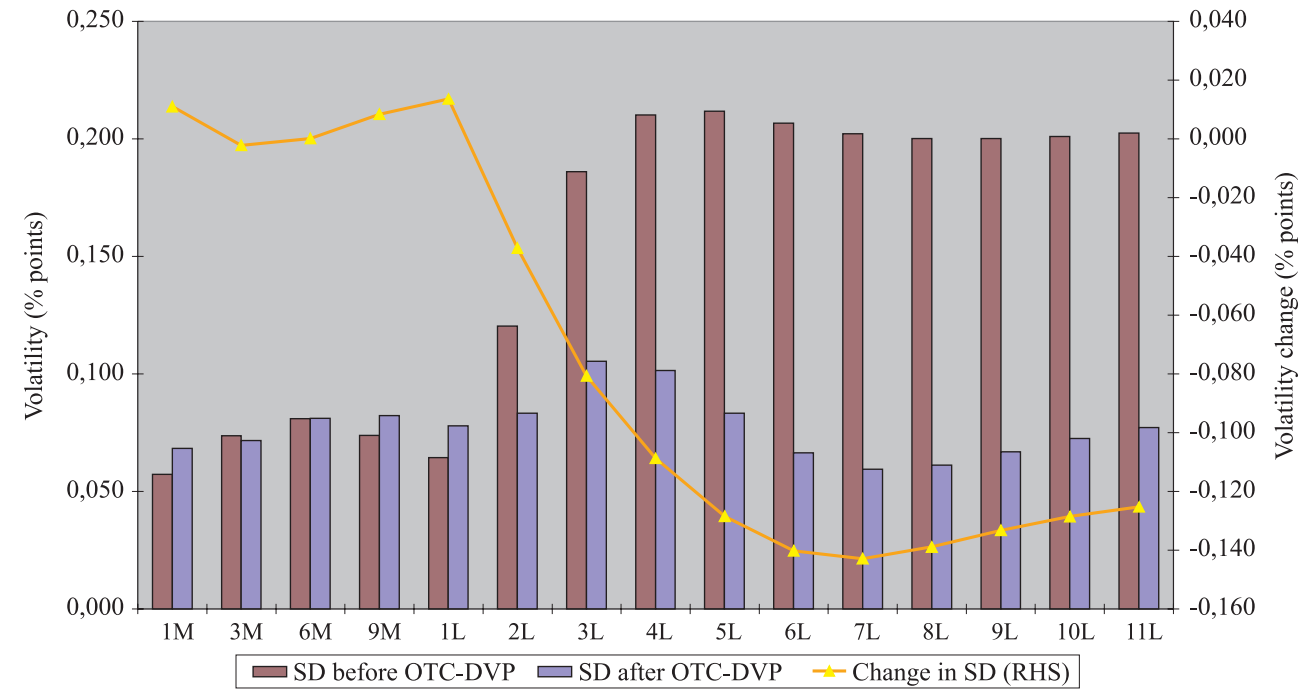

Source: Own calculations 
From volatility analysis it can be concluded that after the parallel bond market introduction the volatility of spot and forward rates has fallen across the maturity spectrum. The paper proves that introduction of parallel bond market with market makers on illiquid government fixed income markets can reduce volatility of interest rates.

\section{Conclusion}

In terms of goodness of fit, Nelson-Siegel model proved to be superior to other methods of statical yield curve estimation in Slovenia. Because of good characteristics method is commonly applied among the most important world central banks and it is robust enough to be applied in financial markets characterized with lack of (long term) fixed income instruments and low liquiditiy. Other more sophisticated methods of statical yield curve estimation proved to be to complex to give economicaly reasonable resoults in current stage of fixed income market development.

From volatility analysis it can be concluded that OTC-DVP bond market introduction (as parallel bond market) has improved the information content of bond prices for term structure estimation purpose. Meassures of goodness of fit have improved significantly after the parallel bond market introduction. The main reason can be found in institutional market makers who have improved liquidity. Consequently instrument prices more acurately represent current market conditions.

After the parallel bond market introduction the volatility of spot and forward rates for mid and long remind maturities has fallen with the highest density on the longest maturity segment. This is extremely important, as volatility represent risk. Reduction in yields volatility is desirable for business purposes as well as for conduction of government policy. In conducting monetary policy in Slovenia 10 year benchmark bond yield is closely observed as one of Maastricht's criteria which have to be implemented before joining the EMU. The paper proves that introduction of parallel bond market can reduce volatility.

\section{References}

Anderson, N., Sleath, J. (2001) New estimates of the UK real and nominal yield curves, London: Bank of England (Working Paper, 126)

Bank for International Settlements (1999) Zero-coupon yield curves: Technical documentation. Basel: BIS

Bolder, D.J., Gusba, S. (2002) Exponentials, polynomials, and Fourier series: More yield curve modelling at the Bank of Canada, Montreal: Bank of Canada (Working Paper, 29) 
Dolenc, P. (2003) "Razvoj sekundarnog tržišta državnim dužničkim vrijednostnim papirima u zemljama u tranziciji”, Financijska teorija i praksa, Vol. 27, No. 2, p. $223-234$

Dombrecht, M., Wouters, R. (1999) "Technical note on the estimation procedure for the Belgian yield curve" In Zero-coupon yield curves: Technical documentation, March, Basel: Bank for International Settlements, p. 1-2

Fisher, M., Nychka, D., Zervos, D. (1994) Fitting the term structure of interest rates with smoothing splines, Atlanta: U.S. Federal reserve board (Working paper)

Grum, A. (2005) "Dolžniški trg in regulativa do upravljavcev pokojninskih skladov", Bančni vestnik, Vol. 54, No. 10, p. 28-31

Jordan, J.V. (1984) "Tax effects in term structure estimation", The Journal of Finance, Vol. 39, No. 2, p. 393-406

Li, B.E. et al. (2001) "Merrill Lynch exponential spline model", London: Merrill Lynch (Working paper)

Litzenberger, R.H., Rolfo, J. (1984) "An international study of tax effects on government bonds", The Journal of Finance, Vol. 39, No. 1, p. 1-22

McCulloch, H.J. (1971) "Measuring the term structure of interest rates", Journal of Business, Vol. 44, No. 1, p. 19-31 30, No. 3, p. 811-830

Meier. I. (1999) Estimating the term structure of interest rates: The Swiss case, Basel: Swiss Institute of Banking and Finance (Working Paper, 9906)

Ministrstvo za finance RS (2004) Poročilo o upravljanju z javnim dolgom Republike Slovenije za leto 2003. Ljubljana: Ministrstvo za finance RS //

http://www.gov.si/mf/slov/tekgib/porocilo_o_dolgu_03.pdf (2.11. 2005) (2004a) Program financiranja proračuna Republike Slovenije za leto 2005. Ljubljana: Ministrstvo za finance RS //

http://www.gov.si/mf/slov/obvezn/prog-fin-internet.pdf (2. 11. 2005)

Nelson, C.R., Siegel, A.F. (1985) Parsimonious modeling of yield curves for U.S. treasury bills, Cambridge: National Bureau of Economic Research (Working paper, 1594)

(1987) "Parsimonious modeling of yield curves", Journal of Business, Vol. 60, No. 3, p. 473-489

Ricart, R., Sicsic, P. (1995) Estimating the term structure of interest rates from French data, Paris: Banque de France (Bulletin Digest, 22)

Schaefer, S.M. (1973) On measuring the term structure of interest rates, London: London Business School Institute of Finance and Accounting (Discussion Paper, IFA-2-74) 
Andraž Grum $\bullet$ The effect of parallel OTC-DVP bond market...

Zb. rad. Ekon. fak. Rij. • 2006 • vol. $24 \cdot$ sv. $1 \cdot 123-140$

(1981) "Measuring a tax-specific term structure of interest rates in the market for British government securities", Economic Journal, Vol. 91, No. 2, p. $415-438$

Schich, S.T. (1997) Estimating German term structure, Frankfurt am Main: Deutsche Bundesbank, Economic research group of the Deutsche Bundesbank (Discussion paper 4/97)

Shea, G.S. (1984) "Pitfalls in smoothing interest rate term structure data", Journal of Financial and Quantitative Analysis. Vol. 19, No. 3, p. 253-269

Steeley, J.M. (1991) "Estimating the gilt-edged term structure: Basis splines and confidence intervals", Journal of Business Finance \& Accounting, Vol. 18, No. 4 , p. $513-529$

Svensson, L.E.O. (1994) Estimating and interpreting forward interest rates: Sweden 1992-1994, Cambridge: National Bureau of Economic Research (Working paper, 4871)

(1995) Estimating forward interest rates with the extended Nelson \& Siegel method. Stockholm: Sveriges Riksbank (Quarterly Review, 3), p. $13-26$

Vasicek, O.A., Fong, G.H. (1982): “Term structure modelling using exponential splines". The Journal of Finance, Vol. 37, No. 2, p. 339-348

Waggoner, D.F. (1997) "Spline methods for extracting interest rate curves from coupon bond prices", Atlanta: Federal Reserve Bank of Atlanta (Working paper 97-10) 


\title{
Učinak usporednog OTC-DVP dužničkog tržišta kapitala na varijabilnost
} tekućih i terminskih kamatnih stopa

\author{
Andraž Grum ${ }^{l}$
}

\section{Sažetak}

U ovom članku prikazana je analiza učinka početka rada OTC-DVP dužničkog tržišta kapitala u Sloveniji na varijabilnost tekućih i terminskih kamatnih stopa $i$ analiza razlike u veličini učinka za različita preostala dospijeća. Za potrebe analize prikazane su ocijene Slovenskih funkcija bez-kuponskih i terminskih kamatnih stopa na tjednoj bazi za upotrebu Nelson-Siegel modela. Po kriterijima kvalitete, primjena Nelson-Siegel model pokazala se bolja od ostalih statističkih metoda koje su bile testirane, a to su: Svensson model, B-splines model, glađen B-splines model i Merrill Lynch eksponenti spline model. Iz rezultata analize može se zaključiti, da je početak rada OTC-DVP tržišta dužničkog kapitala ispravio informacijsku vrijednost cijena dužničkih instrumenta za potrebe procijene vremenske strukture kamatnih stopa. Varijabilnost tekucih i terminskih kamatnih stopa smanjila se za srednju i dugu preostalu dospjelost, s maksimalnom dinamikom za najduže preostalo dospijeće.

Ključne riječi: OTC-DVP tržište dužničkog kapitala, vremenska struktura kamatnih stopa, Nelson-Siegel model, spline interpolacija, varijabilnost prinosa

JEL klasifikacija: G120, G280, C610, C100

1 Magistar, doktorski student na Sveučilištu u Ljubljani, Ekonomski fakultet. Direktor sektora za upravljanje fondovima, Triglav, družba za upravljanje fondovima, d.o.o., Slovenska 54, 1000 Ljubljana, Slovenija. Znanstveni interes: financije. Tel.: +386 51608 798, fax: +38613007 350, e-mail: andraz.grum@triglav-du.si, osobnaweb stranica: http://www.triglav-du.si 